DOI:10.22337/2587-9618-2018-14-3-153-160

\title{
STUDY AND SIMULATION OF HEAT TRANSFER PROCESSES DURING FOAM GLASS HIGH TEMPERATURE PROCESSING
}

\author{
Sergey V. Fedosov ${ }^{1}$, Maksim O. Bakanov ${ }^{2}$, Sergey N. Nikishov ${ }^{1,2}$ \\ ${ }^{1}$ Ivanovo State Polytechnic University, Ivanovo, RUSSIA \\ ${ }^{2}$ Ivanovo Fire Rescue Academy of State Firefighting Service of Ministry of Russian Federation for Civil Defense, \\ Emergencies and Elimination of Consequences of Natural Disasters, Ivanovo, RUSSIA
}

\begin{abstract}
The paper presents basic aspects of simulation of pores formation and growth in the foam glass structure process during raw material mixture high temperature processing. The key mathematical approaches to heat transfer processes simulation and the dynamics of the pores radius growth in the raw material mixture structure are presented. The key assumptions and restrictions allowing representing the most adequate research outcomes at this stage of the subject development are outlined.
\end{abstract}

Keywords: foam glass, heat treatment, mathematical simulation, temperature patterns, surface tension, viscosity

\section{ИССЛЕДОВАНИЕ И МОДЕЛИРОВАНИЕ ПРОЦЕССОВ ТЕПЛОПЕРЕНОСА ПРИ ВЫСОКОТЕМПЕРАТУРНОЙ ОБРАБОТКЕ ПЕНОСТЕКЛА}

\author{
С.В. Федосов ${ }^{1}$, М.О. Баканов ${ }^{2}$, С.Н. Никишов ${ }^{1,2}$ \\ Ивановский государственный политехнический университет», г. Иваново, РОССИЯ \\ ${ }^{2}$ Ивановская пожарно-спасательная академия Государственной противопожарной службы \\ Министерства Российской Федерации по делам гражданской обороны, чрезвычайным ситуациям \\ и ликвидации последствий стихийных бедствий, г. Иваново, РОССИЯ
}

\begin{abstract}
Аннотация: в работе представлены основные аспекты моделирования процесса формирования и роста пор в структуре пеностекла при высокотемпературной обработке сырьевой смеси. Показаны ключевые математические подходы к моделированию процессов теплопереноса и динамики роста радиуса поры в структуре сырьевой смеси. Обозначены основные допущения и ограничения, позволяющие на данном этапе разработки темы представить наиболее адекватные результаты исследования.
\end{abstract}

Ключевые слова: пеностекло, термическая обработка, математическое моделирование, температурные поля, поверхностное натяжение, вязкость

\section{INTRODUCTION}

Improvement of the buildings thermal insulation and housing and utilities infrastructure energy efficiency constitutes one of the energy saving directions. Modern requirements related to building envelopes energy saving determine the use of high-tech materials and systems enabling to solve the issue of the buildings effective thermal protection.

Despite the fact that in recent years the issues of thermal insulating materials range expanding and quality improving has attracted considerable attention the construction market continue to experience shortage in this product.

Insufficient attention is given to assessing the reliability of newly developed materials in buildings envelopes which are often not interlinked with climatic, inventory and logistics and economic conditions of separate regions of our country.

Pursuant thereto, elaboration of physic-andengineering and structural-and-technological basis for energy-efficient materials creation constitutes relevant objective for the construction industry. High-performance thermal insu- 
lating material characterized with cellular structure - foam glass [1] - is gaining increasing urgent imperative.

Foam glass is a highly porous material (80$95 \%$ ), consisting of closed or intercommunicating pores separated by vitrifaction separating partitions [2, 3]. Conventionally, foam glass is produced on the basis of secondary glass cullet or specially welded glass (finely crushed glass), with its full or partial introduction into the raw material mixture composition [4].

Several research directions within which scientists actively conduct their survey are visible in the foam glass technology. One of the directions is to optimize the raw material mixture heat treatment for foamed glass production. The key research method of this direction is the mathematical simulation of thermal processing operations during the foam glass production.

\section{RESEARCH METHODS. PROBLEM STATEMENT}

Thermal processing operations simulation is executed on the basis of heat transfer theory which allows considering intercorrelation of macrophysical characteristics of foamed glass production engineering operation.

Consideration of the process physical foundations is not insignificant because the end material thermal insulating properties are depend directly on other physic-and-engineering characteristics, which change over time and under temperature modification [6].

During the simulation we take the primary environment as the raw material mixture backfilling for foamed glass production in the foaming mold, where the microdomains not filled with crushed glass and gas-forming agents act as pores. The primary system is a chaotic structure, which causes certain difficulties in the process mathematical description, so the necessity in elaboration of the arranged mathematical model reflecting all the primary structure major peculiarities appears.
It is obligatory to formalize both the heat transfer processes and the physical processes taking place when changing the heat treatment modes. With temperature increasing, existing moisture in the raw material mixture starts to evaporate and exits to the furnace chamber for foaming. When the temperature values in the furnace chamber are close to the values when the glass grains melting starts, the backfilling nearsurface layers that are in the immediate contact with the foaming mold metal bezels start to melt first, and somewhat later (in terms of time) the layer, which is heated through convection. The process of backfilling near-surface melting (raw material mixture) takes place - the backfilling central areas are still not heated (due to the surrounding material low thermal conductivity). As a result thereof, the gas-emission sources in these pores do not operate, while the glass particles surrounding this center are already being foamed, and pore radius growth continues in it. Thus, the pore formation material of the charge is formed unevenly, which affects the end product thermal and physical properties quality.

In cases where the temporal parameters for the raw material mixture conditioning during foaming are not sufficient to enable the glass grains melting over the backfill entire volume, the raw material mixture centers need more time for melting, and thus remain not porous. In cases where the foaming period is considerably exceeding the glass grains melting period, fusing of the backfilling near-surface layers takes place since gas production sources completely burn up through warming up, and the glass viscosity decreases, and the molten glass surface tension does not allow delaying a dedicated gas phase in the formed pores spheres, which exits to the furnace chamber for foaming. In such cases, the raw material mixture central part becomes more porous compared to the raw material mixture surface layers.

Thus, we assume that the distribution of temperature patterns over the backfilling of the raw material mixture passes from near-surface areas to the center. The first objective of the research was to determine and describe the temperature 
patterns distribution in the raw material mixture backfilling volume and to identify the patterns of the pore radius growth as a result of its high temperature processing.

The second objective was to determine the conditions for the pores uniform formation over the material volume. Such conditions can be created, for example, through various technical means and technologies, allowing to influence the raw material mixture in real-time, for example, the vibration platforms or ultrasonic treatment application as well as application of powders with different gas-yielding properties (activity), combination of these and other technological influences is possible.

Difficulties which solution requires the heat transfer simplified (or approximate) mathematical models application appear when developing the unified mathematical model able to take into consideration all the above mentioned factors.

As a rule, mathematical physics methods are used for the differential equations solution. In some specific cases, these equations can be solved through numerical methods using computer. However, difficulties related to computational nature arise herewith.

In general case, the heat and substance mass transfer boundary problem can be represented with parabolic type non-linear nonhomogeneous differential equations in particular derivatives:

- heat conductivity boundary problem:

$$
\rho(u, t) \cdot c(u, t) \frac{\partial t(x, \tau)}{\partial \tau}=\frac{\partial}{\partial x}\left[\lambda(u, t) \frac{\partial t(x, \tau)}{\partial x}\right],
$$

where $\rho(u, t), c(u, t), \lambda(u, t)$ - is the thermal properties of the foam glass charge material (density, heat capacity, thermal conductivity), in general case depending on the moisture content and temperature;

- initial condition:

$$
\left.t(x, \tau)\right|_{\tau=0}=t_{0}(x)
$$

- boundary conditions:

$$
\begin{aligned}
& \left.t(x, \tau)\right|_{x=0}=f_{H}(\tau) \\
& \left.\frac{\partial t(x, \tau)}{\partial x}\right|_{x=\frac{L}{2}}=0
\end{aligned}
$$

The initial condition (5) demonstrates that foam glass charge material is characterized with an arbitrary temperature distribution on a coordinate at the moment taken for the reference point.

The boundary condition (6) demonstrates that we have assumed the equality of the mold temperature and material values from which the coordinate $x$ is calculated in the walls contact zone of the metal mold for foaming. Condition (7) indicates that the objective can be considered as a symmetrical one.

It is obligatory to set the boundary conditions and solve the plane problem for one of the coordinates in the modeling early stages. Figure 1 shows the boundary problem of heat transfer in foam glass charge material for the metal mold on the $\boldsymbol{x}$ coordinate.

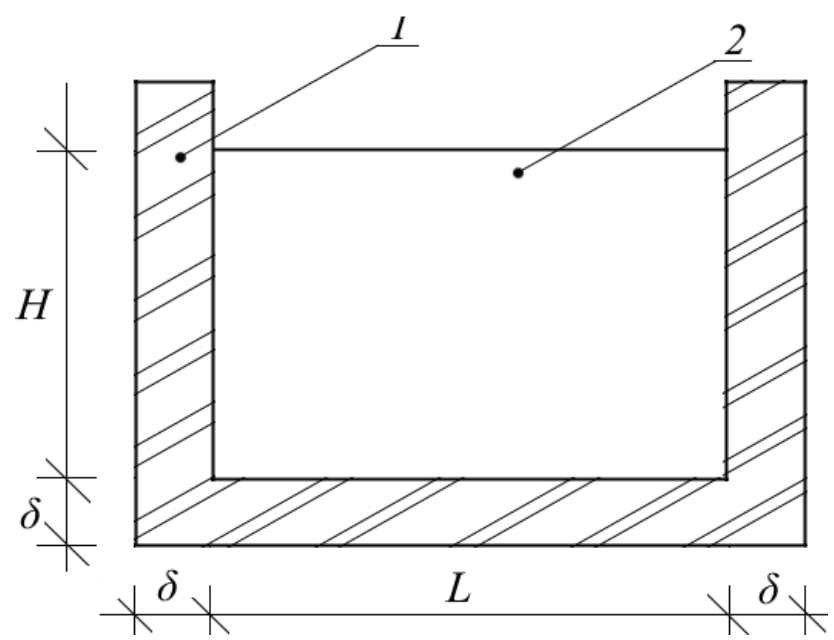

Figure 1. The raw material mixture model (2) - metal mold (1).

Under these conditions the boundary problem of heat transfer in the raw material mixture in metal mold shall be recorded as follows:

$$
\rho c \frac{\partial t(x, \tau)}{\partial \tau}=\lambda \frac{\partial^{2} t(x, \tau)}{\partial x^{2}} ; \tau>0 ; 0 \leq x \leq \frac{L}{2},
$$




$$
\begin{gathered}
\left.t(x, \tau)\right|_{\tau=0}=t_{0}(x), \\
\left.t(x, \tau)\right|_{x=0}=t_{H}, \\
\left.\frac{\partial t(x, \tau)}{\partial x}\right|_{x=\frac{L}{2}}=0
\end{gathered}
$$

Here: $\rho, c, \lambda$ - respectively: the raw material mixture density, heat capacity and thermal conductivity.

Let us introduce dimensionless variables:

$T\left(\bar{x}, F_{O}\right)=\frac{t(x, \tau)-t_{0}}{t_{H}-t_{0}} ; F_{O}=\frac{a \tau}{(L / 2)^{2}} ; \bar{x}=\frac{x}{(L / 2)} ;$

And then the problem (5)-(8) assumes the view:

$$
\begin{gathered}
\frac{\partial T\left(\bar{x}, F_{O}\right)}{\partial F_{O}}=\frac{\partial^{2} T\left(\bar{x}, F_{O}\right)}{\partial \bar{x}^{2}} ; F_{O}>0 ; 0 \leq \bar{x} \leq 1 ; \\
T\left(\bar{x}, F_{O}\right)=\frac{t(x, \tau)-t_{0}}{t_{H}-t_{0}}=T_{0}(\bar{x}) \\
\left.T\left(\bar{x}, F_{O}\right)\right|_{\bar{x}=0}=\frac{t_{H}-t_{0}}{t_{H}-t_{0}}=1 \\
\left.\frac{\partial T\left(\bar{x}, F_{O}\right)}{\partial \bar{x}}\right|_{\bar{x}=1}=0
\end{gathered}
$$

\section{RESEARCH OUTCOMES}

Omitting ordinary but cumbersome conversions, we provide the final solution of the boundary problem in the originals area:

$$
\begin{aligned}
& T\left(\bar{x}, F_{O}\right)=1-\frac{4}{\pi} \sum_{n=1}^{\infty} \frac{1}{(2 n-1)} \sin \left[\frac{\pi}{2}(2 n-1) \bar{x}\right] . \\
& \cdot \exp \left\lfloor-\frac{\pi^{2}}{4}(2 n-1)^{2} F_{O}\right\rfloor+ \\
& \quad+2 \sum_{n=1}^{\infty} \sin \left[\frac{\pi}{2}(2 n-1) \bar{x}\right] \cdot \int_{0}^{1} T_{0}(\xi) . \\
& \cdot \sin \left[\frac{\pi}{2}(2 n-1) \xi\right] d \xi \cdot \exp \left\lfloor-\frac{\pi^{2}}{4}(2 n-1)^{2} F_{O}\right\rfloor
\end{aligned}
$$

Calculation results according to the equation (14) are shown in Figure 2 as curves illustrating the dimensionless temperature change on the dimensionless coordinate depending on the dimensionless process time.

Thus, the equations system (5-8) with initial (2) and boundary (3-4) conditions is called the heat transfer boundary problem and in general demonstrates the temperature patterns distribution in the raw material mixture.

Researchers [7] proposed the model based on the processes time scales during the required porous structure formation in order to describe the pores formation physical process in the raw material mixture melt:

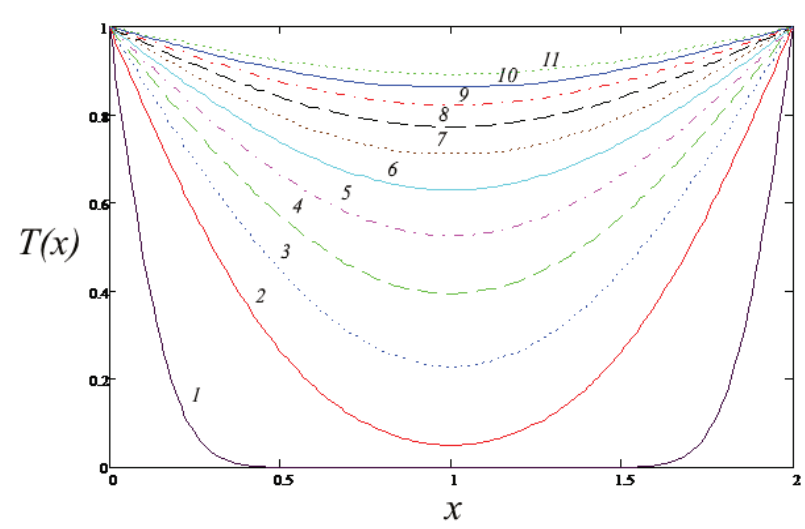

Figure 2. Illustration of calculations to the equation. Fo: 1) 0.01 ; 2) 0.1 ; 3) 0.2 ; 4) 0.3 ; 5) 0.4 ; 6) 0.5 ; 7) 0.6 ; 8) 0.7 ; 9) 0.8 ; 10) 0.9 11) 1 .

$$
\tau_{1}=\frac{h^{2}}{a},
$$

where $\tau_{1}$ - the crushed glass heating period to chalk decomposition temperatures range; $a, \mathrm{~m}^{2} / \mathrm{s}$ - the mixture thermal diffusivity factor; $h, m-$ the typical length scale in the mold volume.

Pores formation due to the gas pressure increase by gas-emission sources takes place in the process second stage:

$$
\tau_{2}=\frac{P_{0}}{a} R^{3}
$$


where $\alpha^{\prime}$ - gas-emission source power factor, $\mathrm{J} / \mathrm{s} ; P_{0}-$ atmospheric pressure, $\mathrm{Pa} ; R$ - pore radius, $\mathrm{m}$.

In describing the second simulation stage the authors used the motion equation of a viscous incompressible fluid (Navier-Stokes) and continuity equation in spherical coordinates, simultaneously noting that the $v$ liquid rate around a bubble has only a radial component, and due to spherical symmetry depends only on $R$ - distance from the pore center (pore radius) and t process time: $v=v(R, t)$. The process second stage model represents a nonlinear differential equation for pores radius $R(t)$ growth over time:

$$
-\frac{3}{2}\left(\frac{d R}{d t}\right)^{2}-R(t) \frac{d^{2} R}{d t^{2}}=\frac{1}{\rho}\left(P_{0}+\frac{\sigma}{R}\right)-\frac{1}{\rho} \cdot \frac{\beta^{\prime}+\alpha^{\prime} t}{R^{3}}+v\left\lfloor\frac{1}{\left(\frac{d R}{d t}\right)} \frac{d^{2} R}{d t^{2}}+\frac{4}{3 R}\left(\frac{d R}{d t}\right)\right\rfloor,
$$

where $\rho$ - melt density of cellular glass charge stock, $\left[\mathrm{kg} / \mathrm{m}^{3}\right] ; R(t)$ - the function of cell radius increase over time; $\alpha^{\prime}$ - power factor of gas generating source, $[\mathrm{J} / \mathrm{s}] ; \beta^{\prime}-$ initial conditions factor, $[\mathrm{J}] ; R-$ cells radius $[\mathrm{m}] ; P_{0}-$ atmospheric pressure, $[\mathrm{PA}] ; \sigma-$ melt surface tension factor of the cellular glass charge stock, $[\mathrm{N} / \mathrm{m}]$. Analysis of the work outcomes related to foam glass porous structure formation suggests using equation (18), which describes the single pore growth:

$$
\frac{\partial R_{1}}{\partial t}=\frac{\frac{3 V_{l}}{4 \pi}+R_{1}^{3}}{\mu \frac{3 V_{l}}{\pi}}\left(\left(p_{\text {int. }}-p_{\text {ext. }}\right) \cdot R_{1}-2 \sigma\right.
$$

where $\mathrm{R}_{1}-$ is the pores inner radius $[\mathrm{m}] ; V_{l}-$ molten glass volume within the pores shell; $\sigma-$ surface tension factor, $[\mathrm{N} / \mathrm{m}] ; \mu-$ fluid dynamic viscosity factor $[\mathrm{PA} \cdot \mathrm{s}] ; p_{\text {int. }}-$ gas pressure inside pore, $[\mathrm{PA}] ; p_{\text {ext }}$ - pressure on the glass melt external (outer) boundary, [Pa].

The Runge-Kutta fourth-order method [8] in the MathCAD program was used for calculations and equation graphical interpretation (18).

Four function values for two intermediate points were used on the following step: two values in the center of the step and the two values at the ends of the step:

$$
k_{1}=h \cdot f\left(t_{i} \cdot R_{i}\right)
$$

$$
\begin{gathered}
k_{2}=f\left(t_{i} \cdot \frac{1}{2} \cdot h, R_{i}+k_{1} \cdot \frac{1}{2} \cdot \Delta R_{i}\right) ; \\
k_{3}=f\left(t_{i} \cdot \frac{1}{2} \cdot h, R_{i}+k_{2} \cdot \frac{1}{2} \cdot \Delta R_{i}\right) ; \\
k_{4}=f\left(t_{i} \cdot h, R_{i}+k_{3} \cdot \Delta R_{i}\right) ; \\
R_{i+1}=R_{i}+\left(k_{1}+2 k_{2}+2 k_{3}+k_{4}\right) \cdot \frac{1}{6} \Delta R_{i}
\end{gathered}
$$

Values $\mu$ and $\sigma$ at calculations are taken as variables.

Changing the values of dynamic viscosity was calculated by the formula $[9,10]$ :

$$
\mu=\mu_{0} \cdot 10^{A \cdot \frac{T_{0}-T}{\left.I(T-B) \cdot(T]_{0}-C\right)},}
$$

where $\mu_{0}$ - factor of dynamic viscosity at the initial moment of time $[\mathrm{Pa} \cdot \mathrm{s}], T o-$ temperature at initial moment of time $[\mathrm{K}], T-$ temperature $[\mathrm{K}]$, A and $\mathrm{B}-$ empirical factors.

Changing the values of surface tension factor calculated by the formula [11]:

$$
\sigma=\sigma_{0}-0,004 \cdot \frac{T-1173}{100},
$$

where $\sigma_{0}$ - factor of surface tension at the initial moment of time $[\mathrm{N} / \mathrm{m}]$.

Temperature change over time was prescribed as follows:

$$
T=T_{0}+k \cdot t
$$


where $k$ - factor taking into account the heating rate, $t$ - time [sec].

Calculations results are presented in Figure 3.

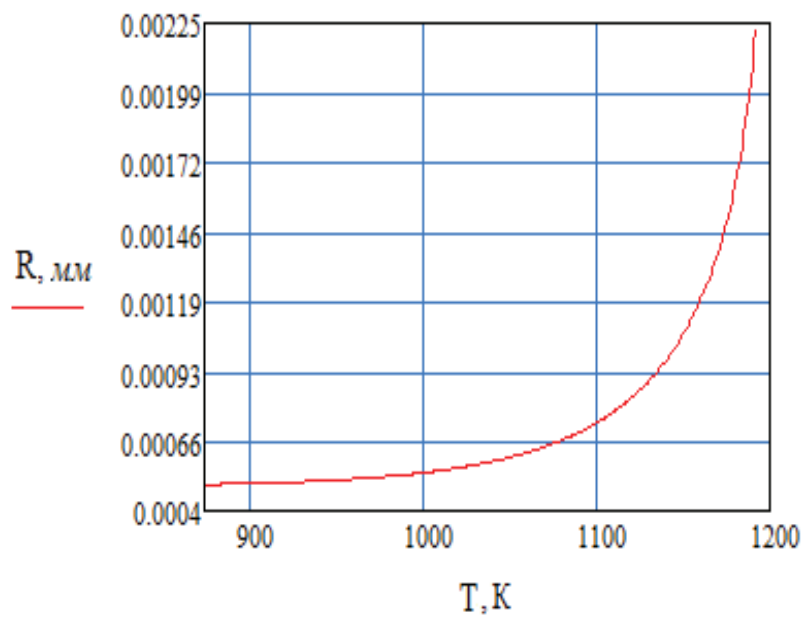

Figure 3. Diagram of pores radius growth depending on the temperature.

\section{OUTCOMES DISCUSSION}

Application of the equation (18) is admissible when making a number of assumptions and allows creating a shared understanding of the foam glass foaming process, since glass melt viscosity indices exert the greatest influence on the bubble growth rate and radius of all the used variables, as the start and end values are characterized by changes from $10^{12}$ to 10 . Glass viscosity value depends on the primary raw material and pursuant to [12] considerably changes in the foaming process (Figure 4).

\section{CONCLUSIONS}

Adequate methods enabling to analytically determine the dependence of the glass melt viscosity on temperature is currently not available, so it is necessary to conduct experimental studies ultimately limiting the mathematical model application only for the particular primary raw materials used in the experiment.
Viscosity, $\mathrm{Pa}^{*} \mathrm{~s}$

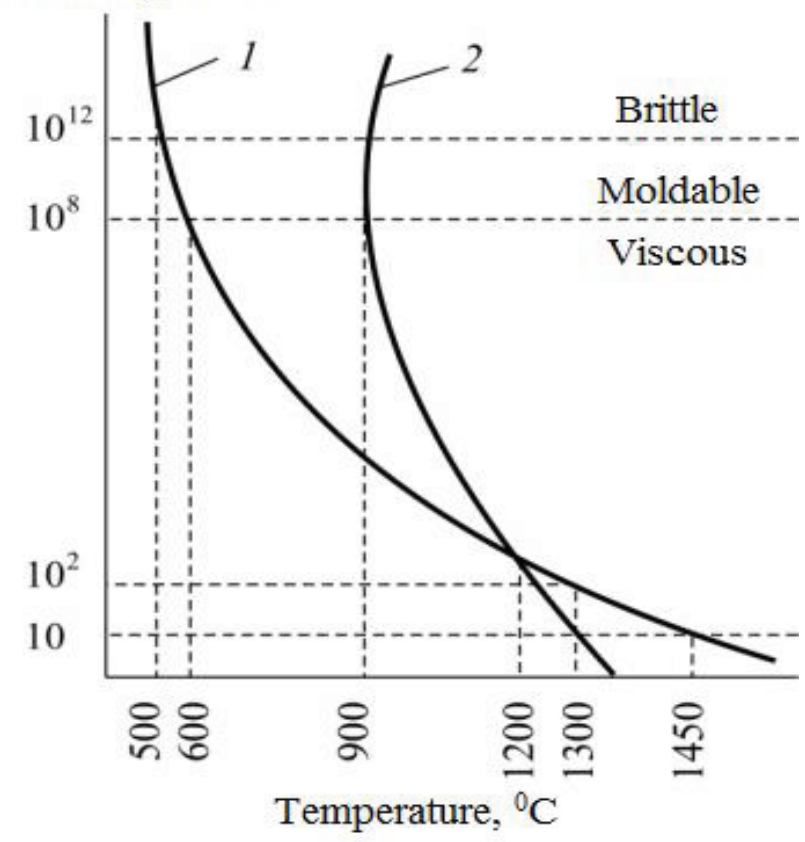

Figure 4. Dependence of the glass melt viscosity on the glass temperature and class: 1 - "Long" glass; 2 - "Short" glass.

The above mentioned suggests that there exists the necessity in mathematical models elaboration capable, with a sufficiently high accuracy, to describe the phenomena occurring at the foam glass porous structure formation during its production, based not only on the thermophysical, but engineering, economic and other factors.

\section{REFERENCES}

1. Minko N.I., Beam O.V., Evtushenko E.I., Arzew V.M., Sergeev S.V. Penosteklo Sovremennyj Jeffektivnyj Neorganicheskij Teploizoljacionnyj Material [Foam Glass is a Modern Effective Inorganic Thermal Insulating Material]. // Fundamental research, 2013, No. 6-4, pp. 849-854.

2. Bobrov Y.L., Ovcharenko E.G., Shoikhet B.M., Petukhova E.Yu. Teploizoljacionnye Materialy i Konstrukcii [Thermal Insulating Materials and Con- 
structions]. Moscow, Infra-Moscow, 2003, 268 pages.

3. Will P.A., Alekseev S.V., Shutov A.I., Mospan V.I. Penosteklo [Foam Glass]. Belgorod, Publishing house of Belgorod State Technological University, 2009, 109 pages.

4. Sigaev, V.N., Zhakipbaev B.E., Spiridonov Iu.A. Ispol'zovanie Gornyh Porod Dlja Poluchenija Penostekla [Rocks Application for Foam Glass Production]. // Glass and Ceramics, 2013, No. 4, pp. 47-50.

5. Fedosov S.V., Bakanov M.O., Nikishov S.N. Variativnost' Podhodov k Matematicheskomu Modelirovaniju Processov Termicheskoj Obrabotki Penostekol'noj Shihty [Variability of Approaches to Mathematic Simulation of Foam Glass Charge Stock Thermal Processing]. // Academic Journal Bulletin of BSTU named after V.G. Shukhov, 2017, No. 11, pp. 110-116.

6. Tsoi P.V. Metody Rascheta Otdel'nyh Zadach Teplomassoperenosa [Calculation Methods of the Heat and Mass Transfer Individual Problems]. Moscow, Energia, 1971, 384 pages.

7. Fedosov S.V., Bakanov M.O., Volkov A.V. Sokol, A.I., Shapochkina Y.A. Matematicheskaja Model' Dinamiki Processa Poroobrazovanija pri Termicheskoj Obrabotke Penostekol'noj Shihty [Mathematical Model of the Pore Formation Dynamics Owing to Heat Treatment of the Foam Glass Batc]. // Journal of Higher Educational Establishments. Chemistry and Chemical Technology, 2014, Vol. 57, Ed. 3, pp. 73-79.

8. Bakhvalov N.S. Chislennye Metody (Analiz, Algebra, Obyknovennye Differencial'nye Uravnenija) [Numerical Methods (Analysis, Algebra, Ordinary Differential Equations)]. Moscow, Nauka, 1975, 632 pages.

9. Sangadiev S.Sh., Munkueva S.B., Sanditov D.S. Opredelenie Parametrov Uravnenija Fogelja-Ful'chera-Tammana Dlja Temperaturnoj Zavisimosti vjazkosti v Oblasti
Perehoda Zhidkost'-Steklo [Determination of the Vogel-Fulcher-Tammann Equation Parameters for Viscosity Temperature Dependence in the Liquid-Glass Transition Area]. // Bulletin of the Buryat State University, 2009, No. 3, pp. 153-156.

10. Lakatos T., Johansson L.-G., Simmingskold B. Viscosity Temperature Relation in the Glass System $\mathrm{SiO}_{2}-\mathrm{Al}_{2} \mathrm{O}_{3}$ $\mathrm{Na}_{2} \mathrm{O}-\mathrm{K}_{2} \mathrm{O}-\mathrm{CaO}-\mathrm{MgO}$ in the Composition Range of Technical Glasses. // Glass Technol., 1972, No. 13(3), pp. 88-95.

11. Scholze H. Glas Natur, Struktur und Eigenschaften. Springer - Verlag, Berlin Heidelberg New York, 1988.

12. Semeinykh N.S. Sapegin G.V. Analiz Ispol'zovanija Razlichnyh Syr'evyh Komponentov v Proizvodstve Granulirovannogo Penostekla [Analysis of Different Raw Materials Components Application in the Granulated Foam Glass Production]. // Bulletin of Perm National Research Polytechnic University. Construction and architecture, 2017, Vol. 8, No. 1, pp. 60-74.

\section{СПИСОК ЛИТЕРАТУРЫ}

1. Минько Н.И., Пучка О.В., Евтушенко Е.И., Нарцев В.М., Сергеев С.В. Пеностекло _ - современный эффективный неорганический теплоизоляционный материал. // Фундаментальные исследования, 2013, №6-4, c. 849-854.

2. Бобров Ю.Л., Овчаренко Е.Г., Шойхет Б.М., Петухова Е.Ю. Теплоизоляционные материалы и конструкции. - М.: Инфра-М, 2003. - 268 с.

3. Воля П.А., Алексеев С.В., Шутов А.И., Мосьпан В.И. Пеностекло. - Белгород: Изд-во БГТУ, 2009. - 109 с.

4. Сигаев В.Н., Жакипбаев Б.Е., Спиридонов Ю.А. Использование горных пород для получения пеностекла. // Стекло и керамика, 2013, №4, с. 47-50. 
5. Федосов С.В., Баканов М.О., Никишов С.Н. Вариативность подходов к математическому моделированию процессов термической обработки пеностекольной шихты. // Вестник БГТУ им. В.Г. Шухова, 2017, № 11, с. 110-116.

6. Цой П.В. Методы расчета отдельных задач тепломассопереноса. - М.: Энергия, 1971. -384 с.

7. Федосов С.В., Баканов М.О., Волков А.В. Сокольский А.И., Щепочкина Ю.А. Математическая модель динамики процесса порообразования при термической обработке пеностекольной шихты. // Известия ВУЗов. Химия и химическая технология, 2014, Том 57, Вып. 3, с. 73 79.

8. Бахвалов Н.С. Численные методы (анализ, алгебра, обыкновенные дифференциальные уравнения). - М.: Наука, 1975. -632 c.

9. Сангадиев С.Ш., Мункуева С.Б., Сандитов Д.С. Определение параметров уравнения Фогеля-Фульчера-Таммана для температурной зависимости вязкости в области перехода жидкость-стекло. // Вестник бурятского государственного университета, 2009, №3, с. 153-156.

10. Lakatos T., Johansson L.-G., Simmingskold B. Viscosity Temperature Relation in the Glass System $\mathrm{SiO}_{2}-\mathrm{Al}_{2} \mathrm{O}_{3}$ $\mathrm{Na}_{2} \mathrm{O}-\mathrm{K}_{2} \mathrm{O}-\mathrm{CaO}-\mathrm{MgO}$ in the Composition Range of Technical Glasses. // Glass Technol., 1972, No. 13(3), pp. 88-95.

11. Scholze H. Glas Natur, Struktur und Eigenschaften. Springer - Verlag, Berlin Heidelberg New York, 1988.

12. Семейных Н.С., Сопегин Г.В. Анализ использования различных сырьевых компонентов в производстве гранулированного пеностекла. // Вестник Пермского национального исследовательского политехнического университета. Строительство и архитектура, 2017, Том 8, №1, c. $60-74$.
Sergey V. Fedosov, Full Member of the Russian Academy of Architecture and Construction Science (RAACS), president of the Ivanovo state Polytechnic University; Ivanovo State Politechnical University; 20, Ul. 8 Marta, Ivanovo, 153037, Russia; phone + 7(4932) 32-85-40; fax +7(4932) 37-19-42; E-mail: fedosov-academic53@mail.ru.

Maxim O. Bakanov, Candidate of technical Sciences, head of Department, Ivanovo Fire Rescue Academy of State Firefighting Service of Ministry of Russian Federation for Civil Defense, Emergencies and Elimination of Consequences of Natural Disasters; 33, Prospekt Stroiteley, Ivanovo, 153040, Russia;

phone+7(4932)34-37-09; e-mail: mask-13@mail.ru.

Sergey N. Nikishov, $\mathrm{PhD}$ student, Ivanovo State Politechnical University; Senior Teacher, Ivanovo Fire Rescue Academy of State Firefighting Service of Ministry of Russian Federation for Civil Defense, Emergencies and Elimination of Consequences of Natural Disasters; 33, Prospekt Stroiteley, Ivanovo, 153040, Russia;

phone+7 (4932)34-37-09; e-mail: mordov5988@mail.ru.

Федосов Сергей Викторович, академик Российской академии архитектуры и строительных наук (РА$\mathrm{ACH})$, профессор, доктор технических наук, президент Ивановского государственного политехнического университета; 153037, Россия, Ивановская область, г. Иваново, ул. 8 Марта, д. 20;

тел. + 7(4932) 32-85-40; факс +7(4932) 37-19-42;

E-mail: fedosov-academic53@mail.ru.

Баканов Максим Олегович, кандидат технических наук, начальник кафедры, Ивановская пожарноспасательная академия Государственной противопожарной службы Министерства Российской Федерации по делам гражданской обороны, чрезвычайным ситуациям и ликвидации последствий стихийных бедствий; 153040, Россия, Ивановская область, г. Иваново, проспект Строителей, д. 33;

тел. +7(4932)34-37-09; e-mail: mask-13@mail.ru.

Никишов Сергей Николаевич, аспирант, Ивановский государственный политехнический университет; старший преподаватель, Ивановская пожарноспасательная академия Государственной противопожарной службы Министерства Российской Федерации по делам гражданской обороны, чрезвычайным ситуациям и ликвидации последствий стихийных бедствий; 153040, Россия, Ивановская область, г. Иваново, проспект Строителей, д. 33;

тел.+7(4932)34-37-09; e-mail: mordov5988@mail.ru. 